\title{
A study of morphological spectrum of testicular and paratesticular lesions
}

\author{
Dhanya K ${ }^{1}$, Sirasagi A.K. ${ }^{2}$ \\ ${ }^{1}$ Dr. Dhanya K., Assistant Professor, ${ }^{2}$ Dr. Anil Kumar Sirasagi, Associate Professor; both authors are affiliated with \\ ESIC Medical College, Kalaburagi, Karnataka, India.
}

Corresponding Author: Dr. Anil Kumar Sirasagi, Associate Professor, ESIC Medical College, Kalaburagi, Karnataka, India. E-mail: aniidhanii5913@gmail.com

\begin{abstract}
Introduction: Testis is affected by both neoplastic and non-neoplastic conditions which can present in all the age groups. Tumor-like proliferations from paratestis often mimic malignancy which results in unnecessary radical orchidectomy. Hence, one has to depend on histopathologic examination for definitive diagnosis. The testicular tumors although relatively rare, are of great interest and importance because of their varied histological appearances. They account for less than $1 \%$ of all malignancies in male. Non-neoplastic lesions or tumor-like proliferations from paratestis often mimic malignancy arising from the scrotal sac which results in unnecessary radical orchidectomy. Hydrocele is often associated with trauma and inguinal hernia, rarely it can be secondary to testicular cancer. Whereas pyocele is most often associated with epididymo-orchitis and less often from contiguous spread of bacterial peritonitis. Hence detailed history and pathological examination are required to know the underlying cause. Objective: To know the morphological spectrum of testicular and paratesticular lesions, their incidence in different age groups, laterality, incidence of benign versus malignant lesions and to study their gross, microscopic features. Methodology: This is a 2 years retrospective study from June 2017 to May 2019 at department of pathology, ESIC Medical college, Kalaburagi. Gross specimens, slides and blocks were retrieved and reviewed. Results: Total 49 cases were studied of which 26 were testicular lesions and 23 paratesticular lesions. Non neoplastic testicular lesions were more common than neoplastic lesions (96.1\% Vs 3.8\%) with majority in the fifth and sixth decade. Right testis was more commonly involved $(59.09 \%)$ than left testis $(31.8 \%)$ and bilateral involvement was seen in 9\% cases. Atrophic testis was most common testicular lesion whereas Pyocele was most common paratesticular pathology. Conclusion: Testis and paratestis can develop both non neoplastic and neoplastic lesions. Gross morphology can give important clues for pathological diagnosis. However there is a crucial role of microscopic examination for definitive diagnosis of these lesions.
\end{abstract}

Keywords: Testicular and Paratesticular Lesions, Pathological Diagnosis

\section{Introduction}

Testes or male gonads are paired organs responsible for production of male gametes, spermatozoa, and secretion of male sex hormones, principally testosterone. Each one is suspended in scrotum by a spermatic cord. Paratestis constitutes the anatomical structures adjacent to testis which includes the testicular collecting system (ductuli efferentes, epididymis, ductus (vas) deferens and ejaculatory duct), the testicular tunics (outer tunica vaginalis, middle tunica albuginea and inner tunica vasculosa) and spermatic cord. The epithelial, mesothelial, and connective tissue elements give rise to a wide variety of pathologic conditions including an

Manuscript received: $4^{\text {th }}$ July 2019

Reviewed: $14^{\text {th }}$ July 2019

Author Corrected: $18^{\text {th }}$ July 2019

Accepted for Publication: 22 $2^{\text {nd }}$ July 2019 interesting array of neoplasms and tumor-like lesions [1]. Testis is affected by both neoplastic and nonneoplastic conditions. Non neoplastic testicular lesions include cryptorchid (undescended) testis, testicular torsion, testicular atrophy, epidermoid cysts, infections of testis like tuberculosis, malakoplakia and vasculitis [2]. Undescended testis is the commonest genital malformation of boys [3]. It is often associated with pain in the groin, torsion, inguinal hernia and potential long-term risks of infertility and malignancy $[4,5]$.

Torsion of testis is a surgical emergency, commonly seen in 10-25 years of age [6]. The testicular tumors although relatively rare, are of great interest and importance because of their varied histological

Pathology Update: Tropical Journal of Pathology \& Microbiology Available online at: www.medresearch.in 750 | P a g e 
appearances. They account for less than $1 \%$ of all malignancies in male [7]. Non-neoplastic lesions or tumor-like proliferations from paratestis often mimic malignancy arising from the scrotal sac which results in unnecessary radical orchidectomy [8]. Hydrocele is often associated with trauma and inguinal hernia, rarely it can be secondary to testicular cancer. Whereas pyocele is most often associated with epididymoorchitis and less often from contiguous spread of bacterial peritonitis [9]. Hence detailed history and pathological examination are required to know the underlying cause.

The incidence and clinical presentation of testicular and paratesticular lesions are variable. The preoperative diagnosis is often difficult with only clinical examination. Hence one has to depend on histopathologic examination for definitive diagnosis.

\section{Aims and objectives}

1. To study the morphological spectrum of testicular and paratesticular lesions.

2. To determine their incidence among various age groups, laterality and incidence of benign versus malignant lesions.

3. To study the gross features and histopathological characteristics of these lesions.

\section{Original Research Article}

\section{Methodology}

Study setting: This study includes 2 years retrospective analysis of all surgical specimens related to testis and paratesticular structures received at Department of Pathology,ESIC Medical College, Kalaburagi, Karnataka, India.

Study period: The study period extended from June 2017 to May 2019.

Study subjects: There were total of 49 cases. It comprised of 26 cases with primary testicular pathology and 23 cases with paratesticular lesions.

Method of data collection: Relevant data like age, clinical presentation, type of surgical procedure were collected from medical records. Gross specimens, slides and blocks were retrieved and reviewed. Hematoxylin \& Eosin stained histopathology slides were studied in detail. Special stains like PAS, Zeil Neilson stain were done wherever necessary. World Health Organization classification was used for classifying the tumors.

Analysis of the data was done to find out the incidence of various lesions, age of presentation, laterality, gross features and histopathological features.

\section{Results}

This is a retrospective study undertaken for a period of 2 years from June 2017 to May 2019. Totally 49 cases related to testicular paratesticular lesions were studied.

Table-1: Histopathological spectrum of testicular and paratesticular lesions.

\begin{tabular}{|l|c|c|}
\hline \multicolumn{1}{|c|}{ Lesions } & Number (n=49) & Percentage \\
\hline Undescended testis & 05 & $10.2 \%$ \\
\hline Atrophic testis & 06 & $12.2 \%$ \\
\hline Torsion testis & 03 & $6.1 \%$ \\
\hline Acute orchitis & 05 & $10.2 \%$ \\
\hline Chronic nonspecific orchitis & 04 & $8.1 \%$ \\
\hline Granulomatous orchitis & 02 & $4.0 \%$ \\
\hline Seminoma testis & 01 & $2.0 \%$ \\
\hline Hydrocele & 08 & $16.3 \%$ \\
\hline Pyocele & 10 & $20.4 \%$ \\
\hline Tunica albuginea cyst & 01 & $2.0 \%$ \\
\hline Varicocele & 03 & $6.1 \%$ \\
\hline Lipoma & 01 & $2.0 \%$ \\
\hline Total & 49 & $100 \%$ \\
\hline
\end{tabular}

Table 1 documents the major histomorphological groups of this study. Pyocele constituted majority, 10 cases (20.4\%) followed by hydrocele 8 cases $(16.3 \%)$ and atrophic testis 6 cases $(12.2 \%)$. Acute orchitis and undescended testis were observed in 5 cases $(10.2 \%)$ each, Chronic nonspecific orchitis in 4 cases $(8.1 \%)$, Tortion testis and Varicocele were seen in 3 cases $(6.1 \%)$ each, Granulomatous orchitis in 2 cases $(4.4 \%)$. Semioma testis, tunica albuginea cyst and lipoma were reported in 1 case $(2.2 \%)$ each. 


\section{Original Research Article}

Table-2: Age wise distribution of testicular and paratesticular lesions.

\begin{tabular}{|c|c|c|c|c|c|c|c|c|c|}
\hline Lesion & $0-10$ & $11-20$ & 21-30 & $31-40$ & 41-50 & $51-60$ & $61-70$ & $71-80$ & Total \\
\hline Undescended testis & 1 & 1 & 2 & 1 & & & & & 5 \\
\hline Atrophic testis & & & 2 & 2 & 1 & 1 & & & 6 \\
\hline Torsion testis & & 2 & 1 & & & & & & 3 \\
\hline Acute orchitis & & & & 1 & 1 & 2 & & 1 & 5 \\
\hline $\begin{array}{l}\text { Chronic Nonspecific } \\
\text { orchitis }\end{array}$ & & & & & 1 & 2 & & 1 & 4 \\
\hline Granulomatous orchitis & & & & & 1 & & 1 & & 2 \\
\hline Seminoma testis & & & & & & 1 & & & 1 \\
\hline Hydrocele & & & & & 1 & 3 & 4 & & 8 \\
\hline Pyocele & & & 1 & 1 & 1 & 2 & 3 & 2 & 10 \\
\hline Tunica albuginea cyst & & & & & & & 1 & & 1 \\
\hline Varicocoele & & & 2 & 1 & & & & & 3 \\
\hline Lipoma & & & & & & 1 & & & 1 \\
\hline Total & 1 & 3 & 8 & 6 & 6 & 12 & 9 & 4 & 49 \\
\hline Percentage (\%) & 2.0 & 6.1 & 16.3 & 12.2 & 12.2 & 24.4 & 18.3 & 8.1 & 100 \\
\hline
\end{tabular}

Age of the patients ranged between 9 and 78 years. There were two cases of undescended testis received from third decade $(40 \%)$ and one case each from first, second and forth decade. Atrophic testis was encountered commonly in third and fourth decades (33.3\%). Torsion testis was common in second decade $(66.6 \%)$. Inflammatory lesions of testis were frequently observed in elderly age groups, sixth decade $(36.3 \%)$ and fifth decade $(27.2 \%)$. Hydrocele and Pyocele were commonly seen in sixth and seventh decade. There were 3 cases of varicocele, most common in third decade $(66.6 \%)$. A single case of bilateral seminoma testis was seen in 52-year-old patient. There was also a single case of tunica albugenia cyst observed in 62-year male and a case of lipoma at the age of 57 years [Table 2].

Among all the specimens received, 44 were radical Orchidectomy specimens. Of these 26 cases (59.09\%) showed Right testis involvement and 14 cases (31.8\%) showed left testicular pathology.

Frequent finding among these specimens were atrophic testicular change ( 8 cases), grossly these testes were reduced in size. Smaller tubules, reduced germ cells, thickened basement membrane and interstitial fibrosis were commonly observed on microscopy. 2/8 cases were associated with acute inflammation, one case showed tightly adherent omental tissue. Remaining 5 specimens were from young males with unknown etiology. Bilateral orchidectomy specimens were received from 4 cases $(9.0 \%)$ which were diagnosed as bilateral Seminoma, Atrophic testis, Fournier's gangrene with testicular abcess and bilateral granulomatous orchitis respectively. All four patients were aged $>40$ years.

Remaining $19(42.2 \%)$ testes were resected secondary to paratesticular lesion.

Single case of malignancy encountered in present study was categorized as Classic Seminoma with bilateral presentation. Here both testes showed homogenous grey white lobulated mass with bulging cut surface. Microscopy showed tumor cells with clear cytoplasm, distinct cell borders, large central nuclei with prominent nucleoli, arranged in nests separated by fibrous septae with lymphocytic and plasmacytic infiltrates.

Histopathological sections from a case of suspected bilateral tubercular orchitis were subjected to Zeil Neilson stain to detect acid fast bacilli, however results were negative. Hence reported as bilateral granulomatous orchitis.

There were 3 varicocelectomy specimens all of which showed dilated and tortuous internal spermatic veins. A case of excised tunica albugenia cyst showed low cuboidal epithelial lining with fibrosed wall, lymphoid aggregates and cholesterol clefts. There was single case of Lipoma arising from parietal layer of tunica vaginalis.

Pathology Update: Tropical Journal of Pathology \& Microbiology Available online at: www.medresearch.in 752 | P a g e 


\section{Original Research Article}

\section{Discussion}

Present study was done on 49 cases which presented with either testicular or paratesticular lesions. Amongst the testicular lesions, there was only one case of malignancy $1 / 26(3.8 \%)$ and rest of the lesions were non neoplastic $25 / 26$ (96.1\%). This is comparable to other studies in which they found similar results [Table 3].

Table-3: Comparison of incidence of benign and malignant testicular lesions.

\begin{tabular}{|l|c|c|}
\hline Authors & Benign lesions & Malignant lesions \\
\hline Reddy H et al [2] & $86 \%$ & $14 \%$ \\
\hline Patel MB et al [6] & $85 \%$ & $15 \%$ \\
\hline Karki S et al [10] & $88.5 \%$ & $11.4 \%$ \\
\hline Deore KS et al [11] & $91.7 \%$ & $8.2 \%$ \\
\hline Sharma M et al [12] & $93 \%$ & $7 \%$ \\
\hline Charak A et al [13] & $90.1 \%$ & $9.8 \%$ \\
\hline Present study & $96.1 \%$ & $3.9 \%$ \\
\hline
\end{tabular}

Whereas amongst the paratesticular lesions, all were benign (100\%). A study by Khandeparker SG et al found $85.1 \%$ benign paratesticular lesions and $14.8 \%$ to be malignant.

In present study, atrophic testis was most common non neopastic testicular lesion, 6/26 (23\%). This is in contrast to other studies where Sharma $\mathrm{M}$ et al [12] and Charak A et al [13] found undescended testis as common benign lesion, Reddy $\mathrm{H}$ et al, Patel MB et al and Abba K et al frequently encountered Torsion testis. Gaikwad SL et al found Acute orchitis as commonest non neoplastic entity [Table 4] [14, 15, 16].

Table-4: Comparison of distribution of non-neoplastic testicular lesions.

\begin{tabular}{|c|c|c|c|c|c|c|c|}
\hline $\begin{array}{c}\text { Non neoplastic } \\
\text { lesions }\end{array}$ & $\begin{array}{c}\text { Reddy } \\
\text { H et al } \\
{[\mathbf{2}]} \\
(\mathbf{n = 8 6})\end{array}$ & $\begin{array}{c}\text { Patel MB } \\
\text { et al [6] } \\
\mathbf{( n = 8 5 )}\end{array}$ & $\begin{array}{c}\text { Sharma } \\
\mathbf{M} \text { et al } \\
{[\mathbf{1 2}]} \\
\mathbf{( n = 5 3 )}\end{array}$ & $\begin{array}{c}\text { Charak } \\
\mathbf{A} \text { et al } \\
{[\mathbf{1 3}]} \\
\mathbf{( n = 7 7 )}\end{array}$ & $\begin{array}{c}\text { Gaikwad } \\
\text { SL et al } \\
{[\mathbf{1 4}]} \\
(\mathbf{n}=\mathbf{1 2 0})\end{array}$ & $\begin{array}{c}\text { Abba K } \\
\text { et al } \\
{[\mathbf{1 5}]} \\
(\mathbf{n}=\mathbf{7 0})\end{array}$ & $\begin{array}{c}\text { Present } \\
\text { study } \\
\mathbf{( n = 2 6 )}\end{array}$ \\
\hline $\begin{array}{c}\text { Undescended } \\
\text { testis }\end{array}$ & $14 \%$ & $8.24 \%$ & $39.62 \%$ & $46.1 \%$ & $15.6 \%$ & $10 \%$ & $19.2 \%$ \\
\hline $\begin{array}{c}\text { Torsion/infarction } \\
\text { testis }\end{array}$ & $22.1 \%$ & $55.29 \%$ & $18.86 \%$ & $15.3 \%$ & $12.8 \%$ & $14.3 \%$ & $11.5 \%$ \\
\hline Acute orchitis & $19.76 \%$ & $16.47 \%$ & $5.66 \%$ & $7.6 \%$ & $18.7 \%$ & $4.3 \%$ & $19.2 \%$ \\
\hline $\begin{array}{c}\text { Granulomatous } \\
\text { orchitis }\end{array}$ & $3.5 \%$ & $9.4 \%$ & $3.77 \%$ & $2.59 \%$ & $6.8 \%$ & $12.9 \%$ & $7.6 \%$ \\
\hline $\begin{array}{c}\text { Chronic nonspecific } \\
\text { orchitis }\end{array}$ & $3.5 \%$ & $9.4 \%$ & $15.1 \%$ & - & $19.7 \%$ & $10 \%$ & $15.3 \%$ \\
\hline Atrophic testis & - & - & $16.98 \%$ & $9.09 \%$ & $9.80 \%$ & - & $23.0 \%$ \\
\hline
\end{tabular}

Undescended testis and acute orchitis were second most common non neoplastic entities observed in present study. There was a single pediatric case of undescended testis whereas as others $(4 / 5$ cases $)$ were aged $>20$ years. Relatively high frequency of malignant tumors is observed in adults with undescended testis as longer the testis resides away from normal location, greater will be the damage to seminiferous tubules. However in present study, none of the adult cases showed malignant features, which is comparable to results of Sharma M et al [12] and Charak A et al [13].

There were 4 cases of Chronic non-specific orchitis (15.3\%) received from age group 40-80 years which is in contrast to results of Reddy $\mathrm{H}$ et al [2] and Kaver et al [17] in which these lesions were common in younger groups between 20 and 45 years. The pathogenesis of these lesions is debatable and probably varied. It may be the end result of previous acute inflammation. However, syphilis, "burnt -out" tuberculosis, inflammatory fibrosing reaction to old sperm granulomas, and filarial infestations may all have to be considered in the differential diagnosis [18].

Pathology Update: Tropical Journal of Pathology \& Microbiology Available online at: www.medresearch.in 753 | P a g e 


\section{Original Research Article}

Pseudotumors or tumor-like proliferations and benign mimickers are seen in paratesticular structures [19]. There were 23 such lesions in the present study study. Majority were Pyocele 10/23 (43.4\%) followed by Hydrocele 8/23(34.7\%), Varicocele 3/23(13.0\%) and one case each of tunica albugenia cyst, lipoma (4.3\%) whereas Charaka A et al [13] and Khandeparker SG et al [16] found Epididymal cyst as most common paratesticular lesion, $40 \%$ and $36.2 \%$ respectively. Epididymitis was not found separately and was in association with orchitis.

In the present study there were 8 cases of Hydrocele of which 6 cases showed secondary changes like thickening of tunics, focal calcification, testicular shape change, Epididymal and cord thickening. According to Michael $\mathrm{H}$ et al [1], large hydrocoele and long duration impairs spermatogenesis and may lead to subfertility or infertility. Dandapat HC et al [20] also proposed that there is a direct relationship between duration of hydrocoele, its size and pathological change.

Histopathologic examination of Pyocele showed varying amounts of acute inflammatory infiltrates, congestion, edema, formation of microabscesses and more confluent areas of suppuration often involving testis [18].

Varicocele constituted $13 \%$ of all the paratesticular lesions and they all showed the characteristic dilated tortuous vessels. The incidence is comparable to study by Mathew T [18] in which varicocele accounted to $9.4 \%$ ccases.

One of the cryptorchid testis showed cystic dilatation of rete testis. These multiple abnormalities associated with cryptorchidism suggest a primary developmental disorder of the mesonephros [21].

A case of paratesticular mass was clinically misdiagnosed as adenomatoid tumor due to its location and expanding nature. However, detailed gross examination showed cystic lesion arising from tunica albugenia with thickened wall, microscopy revealed a fibrosed cyst wall lined by low cuboidal cells, lymphoid aggregates, cholesterol clefts and absence of neoplastic tissue.

\section{Conclusion}

Testis and paratestis can develop both non neoplastic and neoplastic lesions. Benign lesions outnumbered malignant lesions and they were seen in all age groups with predominance between 41 and 60 years.

Right side testis was more commonly involved than left testis. Atrophic change was most common pathologic finding in testis and Pyocele was most common paratesticular lesion.

\section{What this study adds to existing knowledge?}

This study brings out that Gross morphology can give important clues for pathological diagnosis.

However, there is a crucial role of microscopic examination for definitive diagnosis of these lesions.

Funding: Nil; Conflict of Interest: None initiated Permission from IRB: Yes

\section{Author's}

Dr. Dhanya K: Contributed in diagnosis collection of data and editing.

Dr. Anil Kumar Sirasagi: Contributed in manuscript writing, editing and final review.

\section{References}

1.Michael HE, Srigley J. Pathology of the paratesticular region. Urological pathology. Philadelphia: Lippincott Williams \& Wilkins. 2014: 816-817.

2. Reddy H, Chawda H, Dombale VD. Histomorphological analysis of testicular lesions. Ind J Pathol Oncol.2016;3(4):558-563.doi:10.5958/2394-6792.2016. 00104.6

3. Mathers MJ, Sperling H, Rübben H, Roth S. The undescended testis: diagnosis, treatment and long-term consequences. Dtsch Arztebl Int. 2009;106(33):527532.doi: 10.3238/arztebl.2009.0527. Epub 2009 Aug 14

4. Carizza C, Antiba A, Palazzi J, Pistono C, Morana F, Alarcón M. Testicular maldescent and infertility. Andrologia. 1990;22(3):285-288. doi:10.1111/j.14390272.1990.tb01982.x

5. Martin DC. Malignancy in the cryptorchid testis. Urol Clin North Am. 1982;9(3):371-376.

6. Patel MB, Goswamy HM, Parikh UR, Mehta N. Histopathological study of testicular lesions. Gujarat Med J. 2015;70(1):41-46.

7. Adami HO, Bergstrom R, Mohner M, Zatoński W, Storm H, Ekbom A et al. Testicular cancer in nine northern European countries. Int J Cancer 1994;59 (1):33-38. doi: https://doi.org/10.1002/ijc. 2910590108. 


\section{Original Research Article}

8. Tayal U, Bajpai M, Jain A, Khalda, Aditi. Fibrous Pseudo tumor of Right Testis \& Hydrocele of Left Testis - A case report. J Dent Med Sci. 2014;13(11): 65-66.

9. Richard SA, Krieger NK. Pyocele of the scrotum: A consequence of spontaneous bacterial peritonitis. J Urol.1995;153(3 pt 1):745-747.

10. Karki S, Bhatta RR. Histopathological analysis of testicular tumors. J Pathol Nepal. 2012;2(4):301-304. doi: https://doi.org/10.3126/jpn.v2i4.6883

11. Deore KS, Patel MB, Gohil RP, Delvadiya KN, Goswami HM. Histopathological analysis of testicular tumours: A 4-year experience. Int J Med Sci Public Health. 2015; 4(4):554-557. doi: 10.5455/ijmsph. 2015. 12122014114

12. Sharma M, Mahajan V, Suri J, Kaul KK. Histopathological spectrum of testicular lesions-A retrospective study. Indian J Pathol Oncol. 2017;4(3): 437-441.

13. Charak A, Ahmed I, Sahaf BR, Qadir R, Rather AR. Clinico-pathological spectrum of testicular and paratesticular lesions: a retrospective study. Int J Res Med Sci. 2018;6(9):3120-3123. doi: 10.18203/23206012. ijrms20183656

14. Gaikwad SL, Patki SP. Clinico-pathological Study of Testicular and Paratesticular Lesions. Int J Cont Med Res. 2017;4(3):2454-2459.
15. Abba K, Tahir MB, Dogo HM, Nggada HA. Testicular and Paratesticular Non- Neoplastic lesions in University of Maiduguri Teaching Hospital: A 10-year Retrospective Review. Bo Med J. 2016:13(1):39-44.

16. Khandeparkar SG, Pinto RG. Histopathological Spectrum of Tumor and is íp.Tumor-like Lesions of the Paratestis in a is iepiTertiary Care Hospital. Oman Med J. 2015;30(6):461-468. doi: 10.5001/omj.2015.90.

17. Kaver I, Matzkin H, Braf ZF. Epididymo-orchitis: a retrospective study of 121 patients. J Fam Pract. 1990; 30(5):548-552.

18. Mathew T. The pathologic spectrum of paratesticular adnexal diseases: a ten-year review of surgical biopsies. Singapore Med J. 1981;22(6):342-346.

19. Algaba F, Mikuz G, Boccon-Gibod L, Trias I, Arce Y, Montironi R, et al. Pseudoneoplastic lesions of the testis and paratesticular structures. Virchows Archiv. 2007;451(6):987-997. doi: 10.1007/s00428-007-0502-8.

20. Dandapat HC, Padhi NC, Patra AP. Effect of hydrocele on testis and spermatogenesis. Br J Surg. 1990; 77(11):1293-1294. doi: https://doi.org/10. 1002/ bjs. 1800771132 .

21. Jones EC, Murray SK, Young RH. Cysts and epithelial proliferations of the testicular collecting system (including rete testis). Semin Diagn Pathol. 2000;17(4):270-293.

\section{How to cite this article?}

Dhanya K., Sirasagi A.K. A study of morphological spectrum of testicular and paratesticular lesions. Trop J Path Micro 2019;5(10):750-755.doi:10. 17511/jopm.2019.i10.01. 